\title{
Comparative analysis of the polypeptide pattern of cumulus cells during maturation of porcine cumulus oocyte complexes in vivo and in vitro
}

\author{
D Schroeter ${ }^{1}$, B Meinecke ${ }^{2 *}$ \\ 1 Ambulatorische und Geburtshilfliche Veterinaerklink, \\ Justus-Liebig-Universitaet, Frankfurter Str, 106, 35392 Giessen; \\ 2 Institut fuer Reproduktionsmedizin, Tieraerztliche Hochschule, \\ Buenteweg, 15, 30559 Hannover, Germany
}

(Received 8 February 1994; accepted 21 October 1994)

\begin{abstract}
Summary - The protein patterns of porcine cumuli oophori matured as intact cumulus oocyte complexes either in vivo or in vitro with or without $\mathrm{FSH}$ and $\mathrm{LH}$ for $46 \mathrm{~h}$ were investigated. In in vivomatured cumuli oophori, a $53 \mathrm{kDa}$ band disappeared after $24 \mathrm{~h}$ maturation, but reappeared at $46 \mathrm{~h}$. Furthermore, the production of a polypeptide with a relative molecular mass of 44000 ceased and the appearance of 2 other proteins with relative molecular masses of 38000 and 28000 was observed. In cumuli oophori matured in vitro with or without addition of $\mathrm{FSH}$ and $\mathrm{LH}$ the $53 \mathrm{kDa}$ band ceased after a culture period of $12 \mathrm{~h}$. This band was produced again after a culture period of $46 \mathrm{~h}$. In contrast, the polypeptide with the relative molecular mass of 44000 ceased only in cumuli oophori cultures supplemented with $\mathrm{FSH}$ and $\mathrm{LH}$, and the 2 proteins of $\mathrm{M}_{\mathrm{r}} 38000$ and 28000 were detected only in the protein profiles of mature cumuli cultured with FSH and LH. It is concluded that the addition of FSH and $\mathrm{LH}$ to the culture medium is necessary for cumuli oophori to synthesize a protein pattern, which corresponds closely to that produced by cumuli oophori matured in vivo.
\end{abstract}

cumulus cell / polypeptide pattern / oocyte maturation

Résumé - Étude comparative des profils protéiques des cellules du cumulus oophorus pendant la maturation des complexes porcins cumulus-ovocyte in vitro ou in vivo. L'étude porte sur les profils protéiques du cumulus oophorus de porcs maturé sous la forme de complexe intact cumulus-ovocyte, soit in vivo soit in vitro avec ou sans FSH et $L H$ pendant $46 \mathrm{~h}$. Pendant la maturation in vivo, une bande de $53 \mathrm{kDa}$ disparaît après $24 \mathrm{~h}$ mais réapparaît à $46 \mathrm{~h}$. En outre, la production d'un polypeptide d'une masse moléculaire relative de 44000 cesse, simultanément apparaissent 2 autres protéines avec une masse moléculaire relative de 38000 et de 28000 . Pour les cumulus oophorus maturés in vitro avec ou sans addition de $F S H$ et de $L H$, la bande de $53 \mathrm{kDa}$ cesse d'apparaître après une période de culture de $12 \mathrm{~h}$. Cette bande est produite de nouveau après $46 \mathrm{~h}$ de culture. En revanche, le polypeptide d'une masse moléculaire relative de 44000 ne disparaît que dans les cultures de cumu-

\footnotetext{
* Correspondence and reprints
} 
lus supplémentées avec FSH et LH; les 2 protéines de 38000 et 28000 de PMr ne sont aussi seulement décelées que dans le profil protéique des cumulus oophorus cultivés en présence de FSH et de $\mathrm{LH}$. En conclusion, l'addition de FSH et de LH au milieu de culture est nécessaire pour les synthèses protéiques du cumulus oophorus correspondant étroitement à celles produites par le cumulus oophorus maturé in vivo.

cellules du cumulus oophorus / profils protéiques / maturation oocytaire

\section{INTRODUCTION}

Successful fertilization of in vitro-matured pig oocytes is limited by a high occurrence of polyspermy and, in the case of monospermic penetration, by the inability of the ooplasm to transform the sperm head into a male pronucleus. A further defect shown by embryos derived from in vitro-matured oocytes is represented by the failure of zygotes to progress to the blastocyst stage (Motlik and Fulka, 1974; Nagai et al, 1984; Toyoda et al, 1984; First et al, 1988; Parrish, 1991; Rath, 1991).

Recent experiments have shown that somatic support of the oocyte as well as supplementation of the culture medium with gonadotrophins have a beneficial effect on oocyte maturation in vitro. Denuded and/or only corona-enclosed ovine and porcine oocytes resume meiosis in culture but remain developmentally incompetent. In contrast, oocytes supported by cumulus and supplementary follicle cells or oocytes surrounded by the cumulus connected to the whole wall of the extroverted follicle undergo full maturation and subsequently normal embryonic development (Staigmiller and Moor, 1984; Mattioli et al, 1988a; 1989; Galeati et al, 1991). Moreover, the addition of $\mathrm{LH}$ and FSH to the culture medium facilitated and accelerated meiotic progression, and $\mathrm{LH}$ selectively improved cytoplasmatic maturation (Crosby et al, 1981; Mattioli et al, 1991). Gonadotrophins not only support oocyte maturation, but also induce major alterations in the protein profile of follicle and cumulus cells (Ball et al, 1985; Moor and Crosby, 1987).
The fact that $\mathrm{LH}$ induces alterations in the protein synthesis of follicle cells, together with the observation that granulosa cells enhance the fertilizability of oocytes may indicate a causal relationship between the pattern of protein synthesis of the oocyte surrounding follicle cells and oocyte maturation in vivo. On the other hand, the inability of in vitro-cultured porcine and ovine oocytes to undergo normal fertilization and subsequent embryonic development could be related to the protein synthesis pattern of cumulus cells.

The aim of the present study was to compare the protein patterns of porcine cumulus cells matured as intact cumulus oocyte complexes either in vivo or in vitro with or without $\mathrm{FSH}$ and $\mathrm{LH}$ for various time intervals.

\section{MATERIAL AND METHODS}

\section{In vivo maturation}

Oocytes undergoing in vivo maturation were obtained from peripuberal $(80-100 \mathrm{~kg})$ gilts. Follicular growth and ovulation were induced by one im injection of 750 IE PMSG (Intergonan, Vemie, Germany) followed $72 \mathrm{~h}$ later by an im administration of $500 \mathrm{IE} \mathrm{hCG}$ (Ekluton, Vemie) (Hunter and Polge, 1966).

Ovaries were removed by ovariectomy $72 \mathrm{~h}$ after PMSG injection or 9, 21 and $43 \mathrm{~h}$ following the administration of $h C G$. Cumulus oocyte complexes were liberated by slitting the follicles and flushing the follicle content. They were placed in prewarmed $\left(37^{\circ} \mathrm{C}\right)$ Dulbecco's phosphatebuffered saline (PBS, Serva, Heidelberg, Germany) supplemented with $1 \%$ heat-inactivated 
fetal calf serum (FCS, Serva) until labelling with L[ ${ }^{35} \mathrm{~S}$ ]methionine $(500 \mu \mathrm{Ci} / \mathrm{ml}$; specific activity $1280 \mu \mathrm{Ci} / \mathrm{mmol}$, Radiochemical Centre Amersham UK). One or 2 oocytes were separated each time, fixed in ethanol/ acetic acid $(3: 1 \mathrm{v} / \mathrm{v})$ for $24 \mathrm{~h}$, stained with $1 \%$ aceto-orcein and examined at $400 \mathrm{x}$ using phase-contrast optics (Motlik and Fulka, 1976).

\section{In vitro maturation}

Ovaries were collected at a local abattoir from peripuberal gilts into $0.9 \% \mathrm{Na} \mathrm{Cl}$ solution $\left(39.0^{\circ} \mathrm{C}\right)$ and immediately transferred to the laboratory. Cumulus oocyte complexes were released from follicles $3-5 \mathrm{~mm}$ in diameter by scraping the inner surface of the follicular wall with a needle and simultaneous flushing with prewarmed $\left(37.0^{\circ} \mathrm{C}\right)$ PBS containing $1 \%$ heat-inactivated FCS. Cumulus oocyte complexes were examined under a stereo microscope (magnification $40 \mathrm{x}$ ). Only oocytes with a homogeneous ooplasm and surrounded by a compact cumulus oophorus (with or without an attached piece of parietal granulosa cells) were used in this study.

To determine the influence of oocyte nuclear maturation on the protein patterns of cumulus cells, the germinal vesicle of oocytes cultivated in medium with or without gonadotrophins for $21 \mathrm{~h}$ was visualized after centrifugation $(9980 \mathrm{~g}$ for $3 \mathrm{~min}$ ) according to the method of Wall et al (1985). The presence or absence of the germinal vesicle was recorded for each oocyte prior to labelling.

Groups of 15-20 cumulus oocyte complexes were cultured in $2 \mathrm{ml}$ bicarbonate-buffered TCM 199 with Earl's salt (TCM 199, Serva) supplemented with $10 \%$ heat-inactivated FCS either with or without $2.5 \mu \mathrm{g} / \mathrm{ml} \mathrm{FSH} \mathrm{(NIH-FSH-B1,}$ USDA-Reproduction Lab, Beltsville) and $5 \mu \mathrm{g} \mathrm{LH}$ (NIH-LH-B6). Culture of cumulus oocyte complexes was carried out at $39.0^{\circ} \mathrm{C}$ in a humidified atmosphere of $5 \% \mathrm{CO}_{2}$ in air.

\section{Radiolabelling and electrophoresis}

Cumulus oocyte complexes undergoing in vivo maturation were labelled immediately after isolation from the follicles (oocytes in GVI). Cumulus oocyte complexes matured in vitro were labelled
9 (GVI -IV), 21 (GVBD), and $43 \mathrm{~h}$ (M II) after initiation of culture (Motlik and Fulka, 1976). To determine the protein profile of cumulus oocyte complexes at the beginning of culture, cumulus oocyte complexes were labelled immediately after explanation from the follicles.

For L-[35S]methionine labelling, the cumulus oocyte complexes were washed twice with labelling medium: Dulbecco's PBS, containing $0.036 \mathrm{mg} / \mathrm{ml} \mathrm{Na}$-pyruvate, $0.05336 \mathrm{mg} / \mathrm{ml} \mathrm{Na}-$ lactate $(50 \%), 0.99 \mathrm{mg} / \mathrm{ml}$ glucose and $1 \%$ dialyzed heat-inactivated FCS (Biochrom, FRG). Protein synthesis was allowed to proceed by incubating the cumulus oocyte complexes in labelling medium containing L-[35S]methionine for $3 \mathrm{~h}$ at $39.0^{\circ} \mathrm{C}$ in a humidified atmosphere with $5 \% \mathrm{CO}_{2}$, $5 \% \mathrm{O}_{2}$ and $90 \% \mathrm{~N}_{2}$. Cumulus oocyte complexes matured in vitro without gonadotrophins were labelled in groups of 15 in $80 \mu$ l labelling medium under paraffin oil (paraffin oil light, Fisher, Germany). After maturation in vivo or in vitro with gonadotrophins the cumuli oophori were expanded and the cumulus oocyte complexes were labelled individually in $5 \mu$ labelling medium supplemented with hyaluronic acid $(0.025 \% \mathrm{w} / \mathrm{v}$, Sigma, Germany).

After incubation cumulus oophorus cells were separated from the oocytes and from L[35S]methionine by washing twice with PBS by centrifugation at $9980 \mathrm{~g}$ for $6 \mathrm{~min}$. Individual cumuli oophori were placed in $25 \mu$ SDS-sample buffer (Laemmli, 1970) and frozen at $-70.0^{\circ} \mathrm{C}$ until electrophoresis. In order to complete lysis the cumuli were frozen and thawed 3 times. Two microlitres of each sample was used to determine the incorporation of radioactivity into TCAprecipitable material (Van Blerkom, 1978). Aliquots containing equal amount of radioactivity were heated for $1 \mathrm{~min}$ at $95.0^{\circ} \mathrm{C}$ and subjected to 1 -dimensional $8-15 \%$ linear gradient SDS polyacrylamide slab gels $(0.75 \mathrm{~mm}$ thick).

Electrophoresis was carried out according to Laemmli (1970) at $10 \mathrm{~mA}$ per gel. Gels were dried on a Biotec-Fischer-Geldryer under vacuum at $80.0^{\circ} \mathrm{C}$ and subsequently exposed to $X$ ray fitms (Hyperfilm- $\beta$ max, Amersham, UK) for $1-3$ weeks.

A mixture of $\left[{ }^{14} \mathrm{C}\right]$-labelled proteins with a known molecular mass were run simultaneously as standards: myosin (200 kDa); phosphorylase b (92 kDa); bovine serum albumin (67 kDa); ovalbumin $(43 \mathrm{kDa})$; carbonic anhydrase $(30 \mathrm{kDa})$; trypsin inhibitor (21 kDa); and lysozyme $(14.3 \mathrm{kDa})$. 


\section{Statistical analysis of data}

In the protein pattern 4 bands (band $A ; 53 \mathrm{kDa}$; band $\mathrm{B}: 44 \mathrm{kDa}$; band $\mathrm{C}$ : $38 \mathrm{kDa}$; band D: 28 $\mathrm{kDa}$ ) clearly displayed changes during maturation, and were selected for a closer examination. To obtain statistical data the appearance and disappearance of the 4 bands in each protein pattern were recorded as a function of the maturation periods and the presence or absence of $\mathrm{FSH}$ and $\mathrm{LH}$ in the culture medium. The data were analysed using least-square-mean procedure (LSQ) (Harvey, 1976) as a tool for calculating the percentage of cumuli oophori cells in the samples exhibiting the examined band, and qualified to $1=$ not existent, 2 = faint, and 3 = existent. Furthermore, the influence of culture period, the presence or absence of the germinal vesicle after $21 \mathrm{~h}$ of culture, and the addition of $\mathrm{FSH}$ and $\mathrm{LH}$ to the culture medium were calculated by analysis of the variance for each band (Harvey, 1976).

\section{RESULTS}

\section{Nuclear status}

Among the 23 oocytes recovered at $72 \mathrm{~h}$ after PMSG injection or 9 and $21 \mathrm{~h}$ after hCG administration, 20 had an intact germinal vesicle (GV) whereas 3 had undergone germinal vesicle breakdown (GVBD). All of the 7 oocytes examined $43 \mathrm{~h}$ after hCG injection were in metaphase II.

\section{Protein synthesis by cumuli oophori matured in vivo}

The protein patterns of 170 cumuli oophori matured in vivo were analysed. Four protein bands showed major changes during the $43 \mathrm{~h}$ of maturation.

Representative examples of protein pattern synthesized by individual cumuli oophori isolated immediately before, and 9, 21, and 43 after hCG-injection are shown in figure 1. Band $A$ disappeared within $21 \mathrm{~h}$ of matu-
$\mathrm{kDa}$

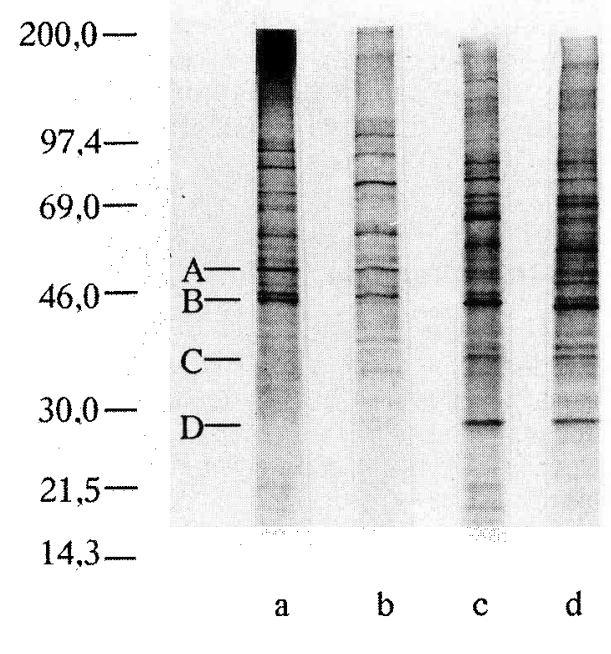

Fig 1. Autoradiodiagrams of L-[35S] methioninelabelled polypeptides from individual cumuli oophori before initiation maturation $(0 \mathrm{~h})$ and 9,21 , and $43 \mathrm{~h}$ after hCG-injection (lanes a-d, respectively). Cumulus-oocyte complexes were removed from the ovaries immediately before $(0$ h) or 9,21 , or $43 \mathrm{~h}$ after hCG-administration and labelled for $3 \mathrm{~h}$. Polypeptides were seperated on SDS polyacrylamide gels $(8-15 \%)$. Changes in the synthesis of selected proteins during maturation (band A: $53 \mathrm{kDa}$; band $\mathrm{B}: 44 \mathrm{kDa}$; band $\mathrm{C}$ : $38 \mathrm{kDa}$; band $\mathrm{D}: 28 \mathrm{kDa}$ ) are indicated by the lines.

ration but reappeared $43 \mathrm{~h}$ after hCG injection. During the maturation period of $43 \mathrm{~h}$ the cumulus oophorus cells ceased the production of band $B$, and bands $C$ and $D$ began to appear.

Table I presents the LSQ-mean analysis of the 4 selected protein bands of cumuli oophori isolated from the follicles $72 \mathrm{~h}$ after PMSG-injection $(0 \mathrm{~h})$. Band $A$ was not detected in any of the analysed protein profiles $21 \mathrm{~h}$ after initiation of maturation. At the end of maturation ( $43 \mathrm{~h}$ ) band A reappeared in all protein patterns of cumuli oophori. When the cumulus-oocyte complexes were labelled before hCG-injection, 
Table. I. LSQ mean of bands A, B, C, and D at $0,9,21$, and $43 \mathrm{~h}$ after initiation of maturation in vivo.

Protein band

Time (h) of maturation in vivo

\begin{tabular}{rrrr}
\multicolumn{1}{c}{0} & 9 & 21 & 43 \\
100.0 & 65.9 & 0.0 & 100.0 \\
83.3 & 19.5 & 70.8 & 0.0 \\
15.3 & 100.0 & 85.3 & 100.0 \\
23.1 & 14.6 & 34.4 & 96.4 \\
39 & 41 & 48 & 42 \\
& & & \\
\end{tabular}

the LSQ mean of the band $B$ value reached 83.3; at $9 \mathrm{~h}$ this dropped to 19.5. The LSQ mean increase to 70.8 at $21 \mathrm{~h}$ and was not detectable at $43 \mathrm{~h}$. Furthermore, during maturation in vivo the cumuli oophori began to produce bands $C$ and $D$. Their LSQ mean increased during $43 \mathrm{~h}$ of maturation from 15.3 and 23.1 to 100.0 and 96.4 , respectively.

\section{Protein patterns of cumuli oophori matured in vitro}

Representative protein profiles of cumuli oophori labelled immediately after isolation from the follicles and after maturation in vitro with or without $\mathrm{FSH}$ and $\mathrm{LH}$ for 9,21 , and $43 \mathrm{~h}$ are shown in figure 2 . The patterns of

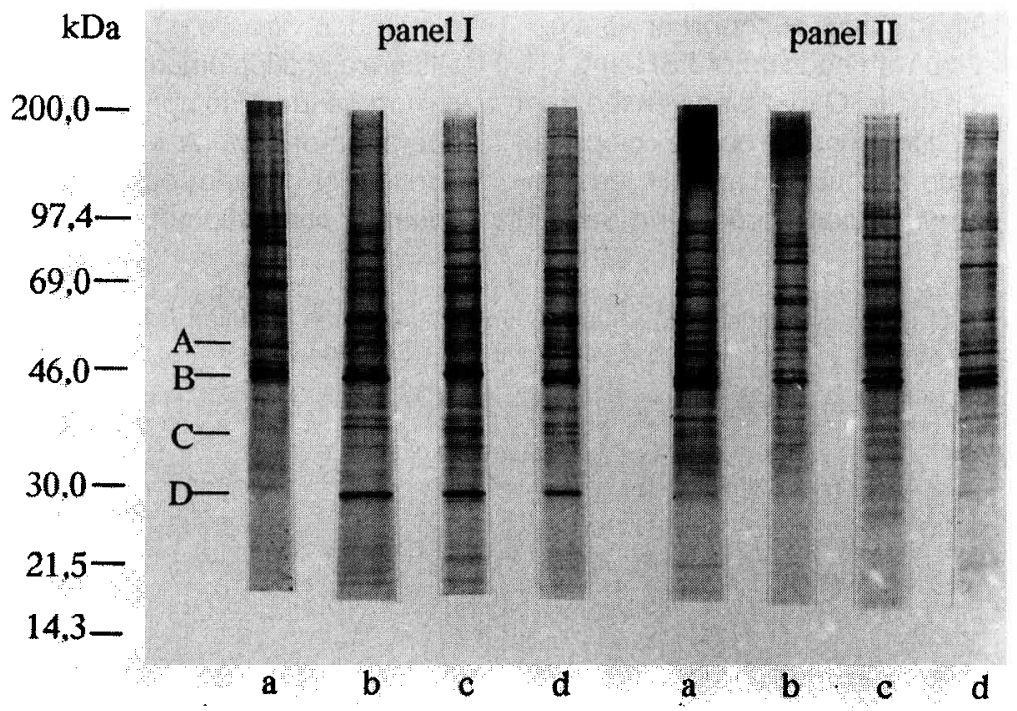

Fig 2. Autoradiograms of $\mathrm{L}-\left[{ }^{35} \mathrm{~S}\right]$ methionine-labelled polypeptides from individual cumuli oophori labelled immediatedly after isolation fom the follicles $(0 \mathrm{~h})$ or 9,21 , or $43 \mathrm{~h}$ (lanes a-d, respectively) after start of culture either with (panel I) or without the addition (panel II) of FSH and LH. Polypeptides were separated on SDS polyacrylamide gels. The lines indicate the 4 bands examined during the culture period. 
proteins synthesized by cumuli oophori cultured in vitro with $\mathrm{FSH}$ and $\mathrm{LH}$ resembled closely those observed when cumuli oophori were matured in vivo. Band $A$ was present before initiation of maturation $(0 \mathrm{~h})$ and at the end of maturation ( $43 \mathrm{~h}$ ). During the 43 $h$ culture period production of band $B$ ceased and the cells started to yield bands $\mathrm{C}$ and $\mathrm{D}$. By contrast, the protein profiles of cumuli oophori cultured without FSH and $\mathrm{LH}$ differed substantially from the protein patterns of in vivo-matured cumuli oophori. Only the alterations of band A corresponded to the changes seen in vivo. These oocytes neither ceased the synthesis of band $B$ nor started the production of bands $C$ and $D$.

Table II presents the LSQ mean of the 4 selected bands from cumuli oophori immediately after isolation from the follicles and after a culture period of 9,21 , or $43 \mathrm{~h}$ either with or without FSH and $\mathrm{LH}$.

Independently of the addition of FSH and $L H$, band $A$ disappeared and after a culture period of $43 \mathrm{~h}$ reappeared. Band $\mathrm{B}$ disappeared only in cumuli oophori that were cultured in vitro with addition of $\mathrm{FSH}$ and $\mathrm{LH}$. Within $43 \mathrm{~h}$ the LSQ mean decreased from 92.6 to 3.0. If the cumulus oocyte complexes were cultured without FSH and $\mathrm{LH}$, the number of cumuli oophori producing band $B$ remained high. The LSQ-mean of bands $C$ and $\mathrm{D}$ demonstrate that only cumuli oophori cultured in the presence of FSH and LH produced band $C$ and $D$ at the end of maturation. The LSQ-mean increased during the 43-h culture period from 0.0 and 2.1 to 95.7 and 91.5 , respectively. The LSQ mean of band $C$ and $D$ from cumuli oophori matured without FSH and LH revealed that the proportion of cumuli oophori containing these 2 bands was low.

These results show that major changes in the protein profiles of cumuli oophori take place during in vivo maturation. Except for band $A$, the alterations in the protein patterns of cumuli oophori matured in vitro depend on the presence of $\mathrm{FSH}$ and $\mathrm{LH}$ in the culture medium.

\section{Effect of FSH/LH and culture period on the protein profile}

The protein patterns of 536 cumuli oophori matured in vitro were used to estimate the influence of supplemented $\mathrm{FSH} / \mathrm{LH}$ and the culture period. The appearance and disappearance of band $A$ were independent of addition of gonadotrophins $(p>0.05)$. By contrast, production of bands $B, C$, and $D$

Table II. LSQ mean of bands A, B, C, and D immediately after isolation from the follicle (0) and after a culture period of 9,21 , and $43 \mathrm{~h}$ with or without $\mathrm{FSH}$ and $\mathrm{LH}$.

Protein band

\begin{tabular}{lrr} 
& \multicolumn{2}{c}{0} \\
& \multicolumn{1}{c}{ FSH/LH } & - \\
\cline { 2 - 2 } & & - \\
\hline & & \\
A (53 kDa) & 97.8 & 92.1 \\
B (44 kDa) & 92.6 & 76.3 \\
C (38 kDa) & 0.0 & 5.3 \\
D (28 kDa) & 2.1 & 0.0 \\
Samples $n$ & 47 & 38
\end{tabular}

Duration of culture (h)

\begin{tabular}{|c|c|c|c|c|c|}
\hline 9 & & 21 & & 43 & \\
\hline $\mathrm{FSH} / \mathrm{LH}$ & - & $F S H / L H$ & - & $F S H / L H$ & - \\
\hline 0.0 & 14.0 & 0.0 & 14.0 & 88.3 & 70.5 \\
\hline 43.7 & 47.5 & 3.3 & 40.4 & 3.0 & 72.1 \\
\hline 71.1 & 13.7 & 92.2 & 11.0 & 95.7 & 32.8 \\
\hline 59.1 & 0.0 & 95.6 & 6.1 & 91.4 & 18.0 \\
\hline 71 & 79 & 45 & 114 & 81 & 61 \\
\hline
\end{tabular}


showed a significant difference $(p<0.001)$ between cumuli oophori which were matured with or without gonadotrophins. The protein profiles of cumuli oophori analysed immediately after isolation from the follicles and after a cultured period of 9,21 , and $43 \mathrm{~h}$ were also significantly different from each other $(p<0.001)$.

\section{Effect of the nuclear status on the protein profile}

Table III presents the LSQ mean of the 4 selected bands from cumuli oophori containing oocytes before and after GVBD at $21 \mathrm{~h}$ after initiation of culture.

The appearance of band $C$ was influenced ( $p=0.001)$ by the nuclear status of the oocytes. This band was more frequent in gels of cumuli oophori belonging to oocytes having undergone germinal vesicle breakdown. Furthermore a weak $(p<0.05)$ influence on the appearance of band $A$ was noticed, and was more frequent in the presence of an intact germinal vesicle.

\section{DISCUSSION}

The present study demonstrates that marked changes occur in the protein pat-

Table III. LSQ mean of bands A, B, C, and D $21 \mathrm{~h}$ after initiation of culture.

\begin{tabular}{|c|c|c|c|}
\hline \multirow{2}{*}{$\begin{array}{l}\text { Protein } \\
\text { band }\end{array}$} & \multicolumn{3}{|c|}{ G erminal vesicle of the ococyte } \\
\hline & Present & Absent & P-value \\
\hline A (53 kDa) & 13.7 & 6.3 & 0.017 \\
\hline $\mathrm{B}(44 \mathrm{kDa})$ & 20.3 & 18.6 & 0.667 \\
\hline $\mathrm{C}(38 \mathrm{kDa})$ & 30.5 & 41.8 & 0.001 \\
\hline $\mathrm{D}(28 \mathrm{kDa})$ & 26.9 & 30.8 & 0.246 \\
\hline Samples $n$ & 114 & 122 & \\
\hline
\end{tabular}

tern of cumuli oophori during maturation of porcine cumulus-oocyte complexes in vivo as well as in cumuli oophori matured in vitro in the presence of FSH and $\mathrm{LH}$. The interpretation of the dynamic changes of polypeptides in the course of in vivo and in vitro maturation needs some caution.

The absence of a band can be either explained by the total absence of synthesis or alternatively by a weak synthesis of unperceptible proteins. Using the present techniques it was not possible to differentiate between these 2 possibilities due to the complex protein profiles of cumulus cells. Therefore, we restricted the present study to 4 bands where clearly discernable changes were visually observed. It should be kept in mind that these polypeptides represent only a very small proportion of the total protein synthetic activity of the cumulus cells. After 1-dimensional electrophoresis each band consists of proteins with equal molecular masses, which might have perhaps different isoelectric points.

Rabahi et al (1991) examined 3 major peaks of the newly synthesized proteins of bovine granulosa and cumulus cells, with molecular masses of 76,56, and $30 \mathrm{kDa}$ before and after the $\mathrm{LH}$ surge. In contrast to the granulosa cells exhibiting a changing pattern of cytosolic proteins, neither the cytosolic nor the secreted proteins of the cumulus cells altered significantly. In the present study the analysis of a large number of proteins patterns of individual porcine cumuli oophori revealed significant differences in the intensity of bands $A, B, C$, and $D$ depending on in vivo or in vitro maturation, as well as on the duration of the maturation period. The start of appearance of bands $C$ (38 kDa) and $\mathrm{D}(28 \mathrm{kDa})$ during maturation is consistent with previous data in other mammalian species. Moor and Crosby (1987) investigated the hormonal regulations and biochemical characteristics of polypeptides secreted by isolated Graafian follicles of sheep. Within $15 \mathrm{~h}$ of the $\mathrm{LH}$ 
surge, the secretion of $M_{r} 46000-60000$ polypeptides had ceased and were replaced by a $M_{r} 30000$ secretion product. The experiments of Landefeld et al (1979) in granulosa cells of rats also showed the synthesis of 2 specific proteins 30 min after treatment with hCG. Furthermore, 4 additional new proteins appeared $3 \mathrm{~h}$ after hCG-injection. The molecular mass of these proteins ranged from 23 000-40 000 Da (Landefeld et al, 1979). These data are in close agreement with the present observations and may reflect common changes in protein synthetic activity of cumulus cells in the course of preovulatory maturation. Despite apparent identical maturation conditions in the in vitro experiments, not all protein patterns showed the typical in vivo alterations. The absence of these changes in protein patterns may be attributable to the inability of these cumuli oophori to respond to hormonal stimuli. This, in turn, may reflect the individuality of cumulus-oocyte complexes. It is possible that the non-responsive cumulus oophori are those which did not undergo complete maturation.

The maturation-dependent protein synthesis during maturation raises the question on the nature and precise role of these proteins. Because of the ability of follicle cells to influence the quality of maturation, the changes in protein synthesis might be relevant for oocyte maturation (Moor and Crosby, 1987; Mattioli et al, 1988a, b). Analysis of the relationship between protein synthesis of cumulus cells and stage of oocyte maturation revealed that only the synthesis of band $C$ is related to the stage of maturation. This conclusion is based on the observation that band $\mathrm{C}$ appears predominantly in the protein pattern of cumulus cells from cumulus-oocyte complexes containing an oocyte after GVBD as compared with that of cumuli oophori from complexes with an oocyte in the GV stage (table III).

In the protein pattern of ovine oocytes, as well as cumulus cells, a band with a molecular mass of $45 \mathrm{kDa}$ was identified as actin. This band was greatly reduced after removal of the cumulus cells (Osborn and Moor, 1982). It has been postulated that this actin belongs to granulosa cell processes that remain within the zona pellucida as a consequence of oocyte isolation procedures (Canipari et al, 1988). During in vivo maturation intercellular coupling persisted up to $32 \mathrm{~h}$ after hCG-injection. However, the functional coupling between cumulus cells and the oocyte in vitro was maintained for only $16 \mathrm{~h}$ (Motlik et al, 1986). Because of the apparent molecular mass of our band $\mathrm{B}$, and since the disintegration of intercellular coupling correlates with the time of disappearance of band $B$ in the protein pattern, we speculate that it may be actin.

Cumulus expansion and mucification of the cumulus oophorus in porcine cumulus oocyte complexes by FSH and LH has been reported (Mattioli et al, 1991). Our data support this observation since only cumuli oophori matured in vivo or in vitro with $\mathrm{FSH}$ and $\mathrm{LH}$ showed expansion and mucification. Cumuli oophori cultured without FSH and $\mathrm{LH}$ remained compact and dense. Therefore, $\mathrm{LH}$ - and $\mathrm{FSH}$-dependent changes in protein synthesis may be related to expansion and mucification of the cumulus oophorus.

Whether the altered proteins have no regulative function but might be products of an activated metabolism during expansion and mucification needs further investigation.

In conclusion, during in vivo maturation of porcine cumuli oophori apparent alterations in the protein synthesis pattern take place. During in vitro culture only the protein patterns of cumuli oophori matured with FSH and $\mathrm{LH}$ correspond to the profile of protein synthesized by cumuli oophori during in vivo maturation. Thus, addition of $\mathrm{FSH}$ and $\mathrm{LH}$ to the culture medium seems to be necessary 
to enable cumuli oophori to produce an in vivo-like protein pattern.

Further investigations of the protein synthesis of cumuli ooophori may help in understanding the importance of somatic support for the oocyte to undergo complete maturation.

\section{ACKNOWLEDGMENTS}

This study was supported by grants of the Deutsche Forschungsgemeinschaft and the Foundation of Reproductive Medicine e V, Giessen. The authors wish to acknowledge with appreciation the skilled technical assistance of B Sonntag and $E$ Podhajsky. We are indebted to $R$ Beuing for his help with the statistical analysis and J Calvete for critical review of the manuscript.

\section{REFERENCES}

Ball GD, Wieben ED, Byers AP (1985) DNA, RNA, and protein synthesis by porcine oocyte-cumulus complexes during expansion. Biol Reprod 33, 739-744

Canipari R, Bevilacqua A, Colonna R, De Felici M, Mangia $F$ (1988) Actin synthesis is not regulated by granulosa cells in mouse growing and preovulatory oocytes. Gamete Res 20, 115-124

Crosby IM, Osborn JC, Moor RM (1981) Follicle cell regulation of protein synthesis and developmental competence in sheep oocytes. $J$ Reprod Fert 62 , 575-582

First NL, Leibfried-Rutledge ML, Sirard MA (1988) Cytoplasmatic control of oocyte maturation and species differences in the development of maturational competence. In: Meiotic Inhibition: Molecular Control of Meiosis (NI First, FP Haseltine, eds) Alan R, Liss, Inc, New York, USA, 1-46

Galeati G, Modina S, Lauria A, Mattioli M (1991) Follicle somatic cells influence pig oocyte penetrability and cortical granule distribution. Mol Reprod Dev 29, 4046

Harvey WR (1976) Statistic program: mixed-model leastsquares and maximum likelihood computer program. Version CDC, Ohio state Univ OH, USA

Hunter RHF, Polge C (1966) Maturation of follicular oocytes in pig after injection of human chorionic gonadotropin. J Reprod Fert 12, 529-531
Laemmli UK (1970) Cleavage of structural proteins during the assembly of the head of bacteriophage T4. Nature (Lond) 227, 680-682

Landefeld TD, Cambell KL, Midgley Jr AR (1979) Rapid changes in the synthesis of specific ovarian granulosa cell proteins induced by human choriogonadotropin. Proc Natl Acad Sci 76, 5153-5157

Mattioli M, Galeati G, Seren E (1988a) Effect of follicle somatic cells during pig oocyte maturation on egg penetrability and male pronucleus formation. Gamete Res 20, 177-183

Mattioli M, Galeati G, Bacci ML, Seren E (1988b) Follicular factors influence oocyte fertilizability by modulating the intercellular cooperation between cumulus cells and oocyte. Gamete Res 21, 223-232

Mattioli M, Bacci ML, Galeati G, Seren E (1989) Developmental competence of pig oocytes matured and fertilized in vitro. Theriogenology 31, 1201-1207

Mattioli M, Bacci ML, Galeati G, Seren E (1991) Effects of $\mathrm{LH}$ and FSH on the maturation of pig oocytes in vitro. Theriogenology 36,95-103

Moor RM, Crosby IM (1987) Cellular origin, hormonal regulation and biochemical characteristics of polypeptides secreted by Graafian follicle of sheep. J Reprod Fert 79, 469-483

Motlik J, Fulka J (1974) Fertilization of pig follicular oocytes cultivated in vitro. $J$ Reprod Fert 36, 235237

Motlik J, Fulka J (1976) Breakdown of the germinal vesicle in pig oocytes in vivo and in vitro. $J$ Exp Zool $198,155-162$

Motlik J, Fulka J, Flèchon JE (1986) Changes in intercellular coupling between pig oocytes and cumulus cells during maturation in vivo and in vitro. $J$ Reprod Fert 76, 31-37

Nagai T, Niwa K, Iritani A (1984) Effect of sperm concentration during preincubation in a defined medium on fertilization in vitro of pig follicular oocytes. $J$ Reprod Fert 70, 271-275

Osborn JC, Moor RM (1982) Cell interactions and actin synthesis in mammalian oocytes. $J$ Exp Zool 220 , 125-129

Parrish JJ (1991) Application of in vitro fertilization to domestic animals. In: Elements of Mammalian Fertilization (PM Wassarman, ed) CRC Press, Boca Raton, Florida, USA 111-132

Rabahi F, Monniaux D, Pisselet C, Chupin D, Durand $P$ (1991) Qualitative and quantitative changes in protein synthesis of bovine follicular cell during the preovulatory period. Mol Reprod Dev 30, 265-274

Rath D (1991) In vitro fertilization (IVF) in pigs. In: Boar Semen Preservation 1I, Proc 2nd int Conf Boar Semen Preservation (Johnson LA, ed), Paul Parey Verlag, Berlin, 199-211

Staigmiller RB, Moor RM (1984) Effect of follicle cells on the maturation and developmental competence of 
ovine oocytes matured outside the follicle. Gamete Res 9, 221-229

Toyoda $Y$, Itagaki $Y$, Minato $Y$, Fukuda $Y$ (1984) Fertilization of pig eggs matured in vivo and in vitro. Proc 10th Int Cong Anim, Repr Artif Insem, 1, 395

Van Blerkom J (1978) Methods for the high-resolution analysis of protein synthesis: application to studies of early embryonic development. In: Methods in Mammalian Reproduction (JC Daniel, ed) Academic Press, New York, USA 67-109

Wall RJ, Pursel VG, Hammer RE, Brinster RL (1985) Development of porcine ova that were centrifuged to permit visualization of pronuclei and nuclei. Biol Reprod 32, 645-651 